\title{
HEALTH EXPENDITURE, EDUCATION AND ECONOMIC GROWTH IN NIGERIA
}

\author{
${ }^{* 1}$ Ojo, T.J., \& ${ }^{2} \mathrm{Ojo}$, S.I. \\ ${ }^{*}$ Department of Economics, Olabisi Onabanjo University, Ago-Iwoye, Ogun-State, Nigeria \\ ${ }^{2}$ Department of Economics, University of Lagos, Akoka, Yaba Lagos State, Nigeria \\ *Corresponding Author Email: ojotopejoshua@yahoo.com Phone: +2348032220613
}

\begin{abstract}
Education and health are crucial ends in and of themselves, as well as important development objectives. Both are critical to the broader idea of expanded human strength, which is at the centre of the notion of growth. The research looks at Nigeria's health expenditure, education, and economic growth, spanning from 1981 to 2019. This paper used principal component analysis (PCA) to calculate variables such as the education expenditure index (EEI) and the health expenditure index (HEI), as well as other explanatory factors such as inflation (INF), life expectancy rate (LER), maternal mortality rate (MMR), and GDP growth. The dependent variable is real GDP. The study used an error correction model (ECM) as an estimating approach. According to the empirical data, government disbursement on education and health has a positive and considerable impact on economic growth and interaction. The results further demonstrate the absence of serial autocorrelation. Furthermore, the report suggests that the government enhance current health and education facilities to encourage economic growth. However, because of the availability and improved health and education services in Nigeria, this policy will decline the appalling state and quality of education and health care, resulting in fewer Nigerians fleeing the country searching for better health and education facilities.
\end{abstract}

Keywords: Education, Health Expenditure, Economic Growth And ECM

JEL Classification: $C 23$; I15; I25; 049

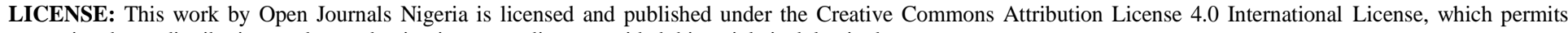
unrestricted use, distribution, and reproduction in any medium, provided this article is duly cited.

COPYRIGHT: The Author(s) completely retain the copyright of this published article.

OPEN ACCESS: The Author(s) approves that this article remains permanently online in the open access (OA) mode.

QA: This Article is published in line with "COPE (Committee on Publication Ethics) and PIE (Publication Integrity \& Ethics)". 


\section{INTRODUCTION}

Investing in health and education has lately become indispensable social priorities because proper human capital enhances workers' skills, efficiency, and standard of living. Moreover, human capital accumulation was a fundamental determinant of economic performance owing to efficiency, and higher economic growth enables more human capital investment. As a result, there are links between economic growth and human capital accumulation via education and health (Eggoh, Hilaire and Gillies, 2015).

Health is a fundamental component of human capital that not only enhances worker efficiency but also increases productivity. A country's economic growth is dependent on its citizens' health. A sound body and mind are necessary for performing everyday life tasks, and a healthy person can enjoy life without relying on others. Spending on health also increases food production and disease awareness. Health improvement can boost economic growth by up to $40 \%$ in developed countries, while increased mortality causes a low change in developing countries (Arora, 2001). In the same vein, no government has maintained consistent economic growth, returns to primary education, science, training, learning-by-doing, and aptitude development (Bedir, 2016).

Education, schooling, science, innovation, knowledge, and training have become essential components of individual and state productivity since the beginning of the twentieth century. Human capital has long been regarded as a critical component of a country's economic growth and development. Education is often considered the most crucial aspect in enhancing human capital quality. As a result, education is essential for a country's social and economic development. No country can achieve long-term economic progress unless its human capital is better educated (Salgur, 2013).

The correct human capital delivery and acceptable functional type requirements are reliable with the asset apportionment model change average education per capita income. Failure to do so results in negligible or even detrimental consequences of intermediate education. Human capital investment would not affect growth unless people can use education inefficient and free markets. The greater the potential for using education and experience in these sectors, the more extensive and efficient (Ozturk, 2001). As a result, this paper aims to look into education and health spending on Nigeria's economy output. The study's essential contribution to the literature is that education and health expenses are not exclusively related to schooling and life expectancy, as most studies believe, but are also a necessary component of economic growth and development. Therefore, this scholarly journal is broken down into five sections. The first section looks at introduction, section two reviews the literature, such as conceptual, theoretical and empirical on education, health expenditure, and economic growth. In the same vein, the third section examines theoretical framework and methodology, we equally consider data presentation, findings and interpretation in section four while section five deals with the conclusion and policy recommendation.

However, the significance of health as a vital ingredient of personal and national growth and economic wellbeing is becoming recognized worldwide. This demonstrates by collecting actions taken by African countries to improve investments in health to meet the health Millennium Development Goals (MDGs). (Serge, C.T. Julius, and M.P. Tieguhong, 2017). 
Education aims to concoct students to live efficiently and dutifully as grownups in future local, national, and global societies, not just to provide them with the standard curricula and school subjects. Furthermore, regardless of their type or nature, schools are the only place where Future intellectuals and leaders can be educated and where high technological levels and the change needed by economic growth can be created (Salgur. 2013).

Nonetheless, only a tiny percentage of these studies have looked at the impact of economic expansion on both primary components of human capital, namely education and health, in both African and developed countries. In the following respects, our empirical analysis varies from earlier studies (Jude, Hilaire, and Gilles, 2015; Titus and Hans, 2015): To begin, we utilize both education and health indicators to analyze the influence of human capital on growth, unlike other studies that focus only on education and health in rich and developing nations. We employ both stock and investment indicators for each human capital component. Second, our research focuses on Jude, Hilaire, and Gilles-Armand (2015). They compare economic growth on education and health in African countries to those in Organization for Economic Co-operation and Development (OECD) nations in Nigerian economic growth.

There has been a divide of opinion in Nigeria over the status of education and health care. Empirical studies suggest that successful government expenditure in both areas can improve the country's growth performance. However, additional research has confirmed that the education and health sectors are the country's two most important growth drivers. In general, the current status of the Nigerian educational and health sectors has sparked various arguments, prompting experts to explore why and what role the government should play in revitalizing and reviving the education and health sectors in Nigeria. (Imoughele and Ismaila, 2013; Adetula et al., 2017).

Over time, there has also been a pattern of persistent and continuous strike action in the education and health care sectors, prompting academics to question whether government investment in these areas is apparent or not. Based on the initial assumption, it is obvious to ask the significant issue impacting Nigeria's educational and health sectors.

According to data from the Central Bank of Nigeria (2020), government spending in both sectors has been dropping, meaning that the government budget in both industries has decreased significantly. For example, between 1990 and 1995, government spending on education went from 2.73 billion to 13.05 billion nairas, while spending on health went from 757.7 million to 5.04 billion nairas. Furthermore, government 44 education expenditures went from 13.0 billion in 1995 to 110.23 billion in 2005, while health spending went from 1.72 billion in 1995 to 21.65 billion in 2005. From 2010 to 2016, healthcare spending increased from 134.11 billion to 250.22 billion dollars. However, between 2016 and 2019, education sector spending fell from 398.35 billion to 392.28 billion, representing a 6.07 billion naira decrease in education spending. Likewise, government expenditure on the health sector fell between 2015 and 2016 but rose from 250.22 billion to 266.22 billion from 2016 to 2019 . With increased spending on the health sector, what is the state of the health sector in Nigeria, given that these sectors contribute to the country's economic growth? Fundamentally, the government's efforts to revitalize and rejuvenate these industries have been useless because they have been ineffectual in causing change, reducing poverty and unemployment, and lowering its crime rate.

Furthermore, mismanagement and underfunding in this area have resulted in the enormous emigration of educated doctors and scholars to other countries that understand the value of investing in education and health. Therefore, the study seeks to examine the impacts of health expenditure regarding the effect of education spending on 
economic growth in Nigeria by separating the expense and computing an index for each sector to identify the immense impact of the sectors on economic growth in Nigeria, grounded on the ongoing challenges in these sectors that have hampered growth (Hanusek and Wobbmann, 2007; Edeme and Nkalu, 2016). Therefore, the study spanning between 1981 to 2019.

\section{LITERATURE REVIEW}

Education and health are fundamental development goals, as well as essential ends in and of themselves. Both are essential to the broader concept of increased human capabilities, which is at the heart of development's meaning. Health is necessary for happiness, and education is needed for a meaningful and satisfying existence; both are crucial components of the broader spectrum of increased human strength at the heart of development's meaning. Simultaneously, education is critical to an emerging country's ability to captivate new knowledge and improve the potential for self-sustained growth and development. Furthermore, good health is a requirement for increased productivity, and good health is also needed for effective education. Consequently, as inputs to the overall output function, health and education can be seen as critical components of growth and development. Thus, health and education are crucial in economic growth because of their double position as inputs and outputs.

\section{THEORETICAL CONSTRUCT}

Endogenous growth theory and Rostow-Musgrave theory of public expenditure growth provide a theoretical link. Education and health expenditure impact economic development and approaches that explain long-term growth due to economic activities that produce newfound knowledge. By utilizing human capital and a knowledge pool that is proportionate to the number of layouts. As a result, the technological creation equation is as follows:

$$
\frac{\partial A}{\partial t}=\delta v H A
$$

Hence, $\mathrm{v}$ denotes the proportion of total human capital assigned to research and development and $\delta$ is a productivity parameter. It seems worth noting that (1) indicates that a fixed rate of growth is sustainable in and of itself. The entire quantity of human capital comprises the total amount of human capital invested in research and development and the overall sum invested in the final goods sector. The fact remains that human capital is a gauge variable is also evident from (1). As a result, an increase in the proportion stock of human capital indicates a quicker pace of knowledge growth from the outside. We would have the same model as Lucas (1988), In the Romer (1990) model if we gauge human capital to one from equation (1) forward, which has the same function as knowledge. The scale variable in the Lucas (1988) model is labour, which is mounted to one. It is worth noting that the research sector requires a lot of human capital and technology. Physical capital $(\mathrm{K})$ is not included in the technological equation; it's only used in the manufacture of finished commodities,

$$
y=[(1-v) H]^{\alpha} \cdot \sum_{i=1}^{A}\left(x_{i}\right)^{1-\alpha}
$$


To this end, Cobb-Douglas production function is based on the production function, which was propounded in 1982 by, that is to say, productivity is an additively removeable function for numerous kinds of capital goods, each of which is constructed according to a diverse design. Note that, $x_{i}$ implies the sum of capital type of $i$. Since all $x_{i}$ go into the production function proportionally, we can have equation (2) as;

$$
y=[(1-v) H]^{\alpha} \cdot K^{1-\alpha} \cdot A^{\alpha}
$$

Assuming the growth rate of human capital should be zero, as in the Romer (1990) model. Obliquely, increasing the share of human capital allocated to technological innovations will boost growth rates and, as a result, final production. However, the reduction in human capital available for final manufacturing will reduce the outcome, at least in the short term.

By ascertaining the necessary conditions for the desired level from optimization of the current value of an endless platform of consumer satisfaction, we will focus on the long effects of various alterations in the contribution of human capital dedicated entirely to final production or the formation of new technologies, as well as steady-state growth rates (U).

$U=\int_{0}^{\infty} e^{-\rho t} \frac{C^{1-\theta}-1}{1-\theta} d t$

We present consumption by. The intertemporal substitution parameter is between zero and one, and the rate of time preference is always positive. The unceasing intertemporal elasticity of substitution (CIES) utility function is the name given to this utility function. The substitutability is constant and equal to $1 / \theta$ across units of consumption at different times. Consumers are less willing to substitute present consumption alternatives with future consumption options when the value is higher (Barro and Salai, 1995), i.e. they are less inclined to sell current consumption for future consumption. According to the innovation formation equation (1) and the economy's budget constraint, the socially optimal rate of growth is obtained by intertemporal maximizing the present value of total utility (U) over an infinite horizon.,

$$
\frac{\partial K}{\partial t}=Y-C
$$

This results in

$$
v=\frac{\delta H-\rho}{\theta \delta H}
$$


Also, $v$ is the percentage of human capital devoted to the development of new technologies? As a result, $\delta H$ it denotes the productivity parameter $v$. It is also worth noting that the scale effect of human capital is still apparent. A rise in the stock of human capital due to exogenous factors would raise the proportion of this stock dedicated to developing new technologies. Because $\mathrm{v}$ must be non-negative and have a maximum value of one, it must be the

situation $\rho \leq \delta H \leq \frac{\rho}{1-\theta}$., $\delta$ indicates positive on efficiency stricture $H$ as well as human capital. Higher human capital productivity in the technology-creating industry leads to a higher allocation of human capital to this sector. A scale effect is implied by the positive relationship between $v$ and the stock of human capital. When the supply of human capital rises exogenously, the proportion of that stock dedicated to creating new technologies rises as well. In theories where human capital inventory grows, this effect is absent (Lucas, 1988). This can be called self-evident because growth in human capital would imply a growing portion of human capital dedicated to developing new technologies.

As a result, the rate of time preference and the intertemporal substitution variable $\theta$ has a negative impact on the share. A lower percentage of human capital is committed to the advancement of technology when time preference is high. Furthermore, current production (and consumption) takes precedence over future consumption alternatives.

As we know from the previous equation (1) that the steady-state growth rate of the individual values matches the projected growth rate $g=v \delta H$, thus,

$$
g=\frac{\delta H-\rho}{\theta}
$$

This implies a change towards future to current consumption, resulting from a decrease in total human capital allocated to enhancing future consumption potentials through research, reducing steady-state growth rate, emphasizing the importance of research and development activities in creating consumption possibilities. On the other hand, a large stock of human capital predicts a faster growth rate because human capital is a scale variable.

\section{EMPIRICAL REVIEW}

Using a Quantile Regression Model and Jei (2019) investigate the link between Government Expenditures and Economic Growth in China and Korea from 1970 to 2015. According to the empirical data, government spending on health and education has a favourable and considerable impact on economic growth in both countries.

Wong Sing Yun (2021) use the Johansen co-integration technique and the Vector Error Correction Model to empirically examine the link between education expenditure, health care expenditure, and economic growth in Malaysia from 1980 to 2012. (VECM). There is a long-term positive and robust association between public education investment and healthcare spending on economic growth. 
Karim (2016) used the ARDL bounds testing method to examine the relationship between health expenditure and economic growth in Nigeria from 1985 to 2009. He discovered that health spending has little impact on economic growth. The findings reveal that healthcare expenditures have little effect on Nigeria's economic growth despite improving human capital and lowering infant mortality rates.

Using a multiple regression model, Ojewumi and Oladimeji (2016) investigated the impact of government financing on educational growth in Nigeria from 1981 to 2013. The main finding was that recurrent expenditure had a detrimental influence on academic development.

Eggoh, Houeninvo, and Sossou (2015) used traditional cross-section and dynamic panel techniques to examine the relationship between human capital (education and health) and economic growth for a large sample of 49 African countries from 1996 to 2010. They discovered that public expenditures on education and health harm economic growth, whereas human capital positively impacts.

In the same vein, Taiba, Boussalem, and Boussalem (2014) used co-integration and causality in ECM analysis to examine the relationship between public spending on health and economic growth in Algeria: Testing for Co-integration and Causality from 1974 to 2014. Again, the data demonstrated long-run causation between public health spending and economic growth but no short-run causation between public health spending and economic development.

In general, empirical studies on the impact of health and education expenditure on economic growth have been established in the literature (Eggoh, Houeninvo, and Sossou, 2015; Churchill, Yew, and Ugur, 2015; Kareem, Samuel, Olusegun, Arogundade, and Rasaq, 2017; Yun and Yusoff, 2018; Wahab, Oluwanisola, Zurina, \& Nurhazirah (Imoughele and Ismaila, 2013; Mallick, Das and Pradhan; 2016; Ayeni and Omobude 2018). Though some, to the best of the researcher's knowledge, no study has been able to disaggregate the components of health and education expenditure to compute an index using principal component analysis (PCA) to get the index of each cost because most studies only looked at recurrent spending on education and health, ignoring capital expenditure. In light of this, this research aims to push the boundaries of knowledge by focusing on the effects of health and education expenditure on economic growth using PCA analysis to create an index of education and health expenditure.

\section{STYLIZED FACTS}

This study sub-section presents the facts of stylization as shown in Figure below 


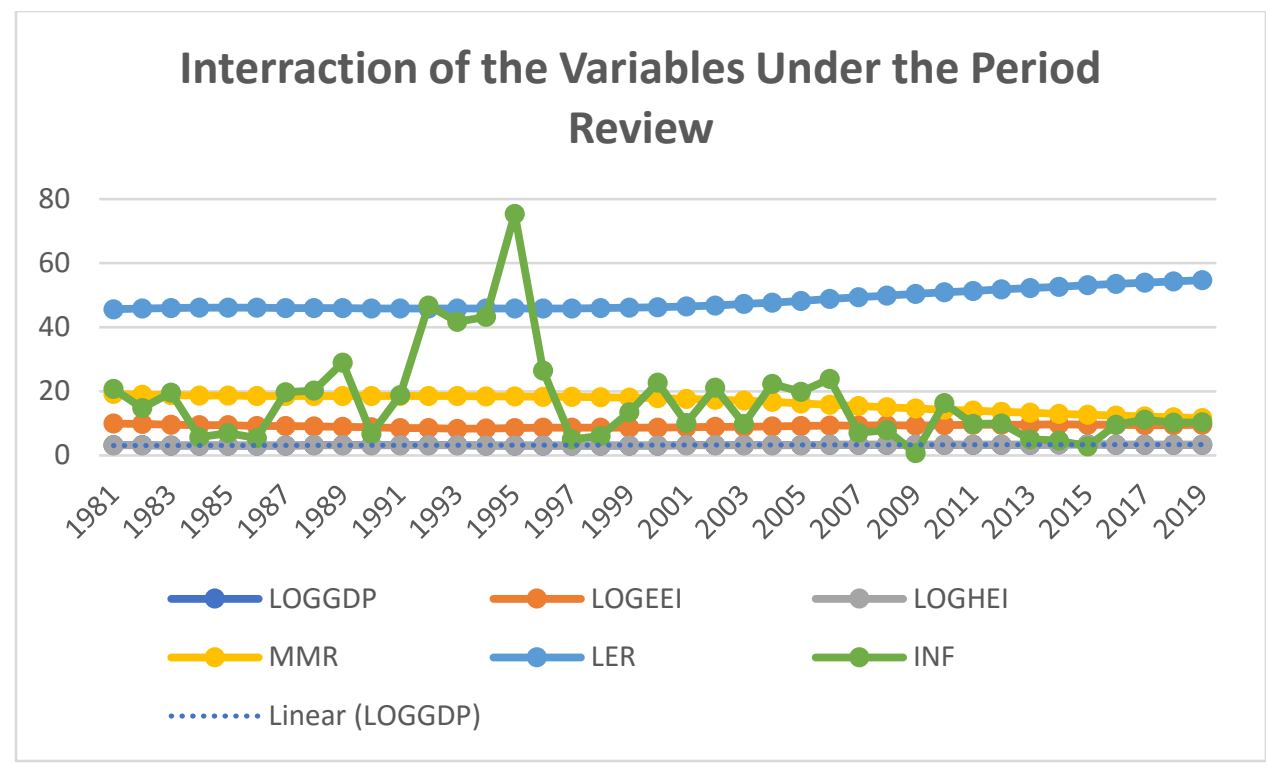

Source: Researcher's Computation

As shown in the graph above, the variables included in the study fluctuate continuously, making it difficult for the Nigerian economy to expand steadily during the period under consideration. For example, the inflation rate fluctuated a lot during that time, especially between 1981 and 1991, and it peaked between 1993 and 1996, which slowed down economic growth and development. Other variables, such as the life expectancy rate, also fluctuate during the period under consideration. However, looking at the trend line, economic growth was below average from 1992 to 2004, then above normal from 2005 to 2019.

\section{METHODOLOGY AND MODEL SPECIFICATION}

Error correction model was adopted for this study, owing to the fact, we have all our variables stationary at first difference. However, numerous empirical studies have used Solow's growth model to understand better economic growth dynamics concerning the factors that cause growth variations between industrialized and developing countries (Akpan and Atan, 2015). For example, the current study looked at the influence of health and education spending on Nigeria's economic growth. The endogenous growth theory explains the many driving growth variables because it deals with labour, capital, and human capital development. Classical theorists, for example, placed a greater focus on the role of money in influencing economic growth. In contrast, endogenous theorists extended Solow's model to include labour technology and education investment in the growth model.

On the other hand, the Solow model has a significant fault in that it depends on many conservative assumptions that aren't valid in developing countries. A major criticism is a complexity in defining the role of technological progress within the model's structure and the model's incapacity to explain the significant residual disparities observed between countries with similar technologies (Mohammed Gabel and Karlsson, 2013). Because of its unpredictability, the endogenous growth model is more suited for our investigation. The endogenous growth model has the following parameters: 


$$
Y_{i}=A K_{i}^{\alpha} L_{i}^{1-\alpha} K^{-\beta}
$$

Where $A$ denotes the efficiency parameter, knowledge or labour effectiveness, $K$ is physical capital and $L$ denotes labour. Equation (8) is expanded to include investment in human capital.

$$
\ln Y_{t}=\ln A_{t}+\alpha \ln K_{t}+\beta \ln H_{t}+\mu \text {. }
$$

Where $Y$ represents honest $G D P, K$ represents physical capital, $H$ represents human capital, $\alpha$ and $\beta$ are parameter coefficients, and $A$ represents the efficiency parameter or constant.

\section{MODEL SPECIFICATION}

Because it is most appropriate for the work to invest the influence of education and health expenditure on economic growth in Nigeria, this study will use a dynamic short-run Error correction model as the estimating approach. The Mallick, Das, and Pradhan (2016) model was adapted for this study since the authors looked at the impact of education spending on economic growth in Asian countries. The author's model is described as follows:

$G D P_{t}=\alpha_{1}+\beta_{1} E X E_{t}+\varepsilon_{t}$

Where $G D P_{t}$ stands for the gross domestic product at a time $t, E X E$ stands for education expenditure, $\alpha$ is the intercept, $\beta$ is the parameter, $\varepsilon$ and is the error term. The model has been altered as follows:

$G D P=f(E E I, H E I, M M R, L E R, I N F)$

$G D P$ It stands for gross domestic product $E E I$ stands for education expenditure index, $H E I$ stands for health expenditure index $M M R$, is for maternal mortality rate, and $L E R$ is for life expectancy rate and $I N F$ stands for inflation. The above is also described in $A R D L$ the form, as follows:

$$
\begin{aligned}
& \Delta G D P_{t}=\alpha_{0}+\sum_{i=1}^{p} \alpha_{1} \Delta G D P_{t-1}+\sum_{i=0}^{p} \alpha_{2} \Delta E E I_{t-1}+\sum_{i=0}^{p} \alpha_{3} \Delta H E I_{t-1}+\sum_{i=0}^{p} \alpha_{4} \Delta M M R_{t-1} \\
& +\sum_{i=0}^{p} \alpha_{5} \Delta L E R_{t-1}+\sum_{i=0}^{p} \alpha_{6} \Delta I N F_{t-1}+E C M_{t-1}
\end{aligned}
$$

Where $\Delta$ is the first difference operator, $G D P$ is the gross domestic product, $E E I$ is the education expenditure index, $H E I$ is health expenditure, $L E$ is life expectancy rate, $M M R$ is the maternal mortality rate, and $I N F$ is the inflation rate, and $p$ is the lag length, $\alpha \& \beta$, are the parameters to be estimated, and $\varepsilon t$ is the time interval. 


\section{Sources and Measurement of Data}

\begin{tabular}{llll}
\hline Variables & Description & Source & Measurement \\
\hline Economic Growth & Proxied with Real Domestic & World Bank Development & GDP Annual Growth Rate \\
& $\begin{array}{l}\text { Product } \\
\text { Education }\end{array}$ & Indicators (WDI) & \\
Expenditure & $\begin{array}{l}\text { Computed using Principal } \\
\text { component analysis (PCA) }\end{array}$ & Indicators (WDI) & Expenditure on Education \\
Health Expenditure & $\begin{array}{l}\text { Health Expenditure Index } \\
\text { Computed using Principal }\end{array}$ & World Bank Development & Capital and Recurrent \\
& component Analysis (PCA & & Expenditure on Health \\
Maternal Mortality & Proxied with number of & World Bank Development & Measured in thousands \\
Rate & Death of Pregnant Women & Indicators (WDI) & \\
Life Expectancy & Life Expectancy & World Bank Development & The average number of \\
& & Indicators (WDI) & years people can live \\
Inflation & Inflation Rate & World Bank Development & Consumer Price Index \\
& & Indicators (WDI) & (CPI)
\end{tabular}

Source: Author's Computation using Data Haul Out from WDI, 2019

\section{EMPIRICAL RESULTS AND FINDINGS}

\section{DESCRIPTIVE STATISTICS}

$$
G D P=f(E E I, H E I, M M R, L E R, I N F)
$$

These descriptive statistics, therefore, provide historical context for our data's behaviour. The variables examined here are gross domestic product $(G D P)$, education expenditure index $(E E I)$, health expenditure index $(H E I)$, life expectancy rate $(L E R)$, the maternal mortality rate $(M M R)$ and inflation rate $(I N F)$, which are presented in Table 1 below: 
Table 1: Descriptive Statistics Result

\begin{tabular}{llllcllll}
\hline Variable & Mean & Median & Max. & Min. & Std. Dev. & Jarque-B. & Prob. & Obs. \\
\hline LOGGDP & 3.234195 & 3.196806 & 3.406620 & 3.119705 & 0.104736 & 4.655856 & 0.097498 & 39 \\
LOGEEI & 9.151992 & 9.226469 & 9.919960 & 8.334353 & 0.434244 & 2.628556 & 0.268668 & 39 \\
LOGHEI & 3.234195 & 3.196806 & 3.406620 & 3.119705 & 0.104736 & 4.655856 & 0.097498 & 39 \\
MMR & 16.54244 & 17.89500 & 19.14900 & 11.63000 & 2.466735 & 5.175370 & 0.075194 & 39 \\
LER & 48.27713 & 46.26700 & 54.68700 & 45.63700 & 3.025038 & 6.033376 & 0.048963 & 39 \\
INF & 16.94618 & 11.11892 & 75.40165 & 0.686099 & 14.58211 & 70.64500 & 0.000000 & 39
\end{tabular}

Source: Author's Computation Using Data Extracted From WDI, 2019

According to Table 1, the average gross domestic product growth rate was 3.23 per cent, indicating that the economy grew at an average rate of 3.19 per cent, compared to a median value of 3.19 per cent. Furthermore, the average education expenditure index, which includes both capital and recurrent education spending, is 9.15 per cent, which is lower than the median figure of 9.22 per cent. This indicates a decrease in educational expenditure. Furthermore, the average mean value for the health expenditure index, which includes both capital and recurring health expenditure, is 3.23 per cent, somewhat higher than the median value of 3.19 per cent. In addition, the average mean inflation rate is 16.94 per cent, compared to 11.11 per cent for the median rate. This means that the country's inflation rate has increased by 16.94 per cent yearly. In addition, the average life expectancy rate is 48.27 per cent, which is greater than the median value of 46.26 per cent. This means that a person can expect to live for around 48 years and three months on average. In addition, the estimated average maternal death rate is 16.54 per cent lower than the median figure of 17.89. This means that 17.89 per cent of maternal deaths occur due to problems during pregnancy or childbirth.

Furthermore, the standard deviation for all variables is more significant than 1.0, i.e. 5.11. The probability value of the Jarque-Bera statistic for all variables also indicates that their distribution levels are all at mean zero. This demonstrates that the analysis is correct and fit. 
Table 2: Phillips-Perron Stationarity Test

\begin{tabular}{lccccccc}
\hline Variables & \multicolumn{3}{c}{ Level } & \multicolumn{3}{c}{ First Difference } \\
& PP t. Stat. & $\mathbf{1 \%}$ & $\mathbf{5 \%}$ & $\mathbf{P P}$ t. Stat. & $\mathbf{1 \%}$ & $\mathbf{5 \%}$ & Order of \\
& & & & & & Integration \\
\hline LOGGDP & -0.3114 & -3.6155 & -2.9411 & -3.8744 & -3.6210 & -2.9434 & I (1) \\
LOGEEI & -1.7120 & -3.6155 & -2.9411 & -3.5221 & -3.6210 & -2.9434 & I (1) \\
LOGHEI & -0.3114 & -3.6155 & -2.9411 & -3.8744 & -3.6210 & -2.9434 & I (1) \\
MMR & -2.7136 & -3.6155 & -2.9411 & -4.1294 & -3.6210 & -2.9434 & I (1) \\
LER & -2.3927 & -3.6155 & -2.9411 & -5.9721 & -3.6210 & -2.9434 & I (1) \\
INF & -3.2350 & -3.6155 & -2.9411 & -10.4556 & -3.6210 & -2.9434 & I (1) \\
\hline
\end{tabular}

Note: $* * *$ significant at $1 \%$, ** significant at 5\%, Mackinnon critical values are shown in parenthesis. The lagged numbers shown in brackets are selected using the minimum Schwarz and Akaike Information criteria

Source: Author's Computation Using Data Extracted From WDI, 2019

The Philip-Perron stationarity test confirmed that gross domestic product (GDP), education expenditure index (EEI), health expenditure index (HEI), the maternal mortality rate (MMR), life expectancy rate (LER), and inflation rate (INF) are all stationary at the first difference for both $1 \%$ and 5\% significance. This shows that the model's integrated series have no unit root, implying that they are mean reverting and approaching their long-run equilibrium.

\section{CO-INTEGRATION TEST}

Since all the variables are stationary at the first difference, we must run Engle-Granger co-integration test to ascertain the long-run equilibrium relationship among variables estimated in the model.

Table 3: Co-integration Test Estimate

\begin{tabular}{lllll}
\hline \multicolumn{1}{c}{ Dependent } & \multicolumn{1}{c}{ Tau-Stat. } & Prob* $^{*}$ & Z-Stat. & Prob* \\
\hline INF & -5.163806 & 0.0339 & -54.79392 & 0.0000 \\
LER & -2.244350 & 0.9800 & -9.551217 & 0.9828 \\
LOGEEI & -5.608296 & 0.0420 & -35.85893 & 0.0386 \\
LOGGDP & -2.078734 & 0.9705 & -7.314882 & 0.9856 \\
LOGHEI & -2.424335 & 0.9244 & -9.157344 & 0.9622 \\
MMR & -3.210070 & 0.7869 & -16.77376 & 0.7817 \\
\hline
\end{tabular}

Source: Author's Computation Using Data Extracted From WDI, 2019

The Engle-Granger co-integration revealed four cointegrating equations, implying a long-run relationship between education spending index, health expenditure, life expectancy rate, maternal mortality rate, inflation, and GDP growth. However, because most variables cointegrate in the long run, we will further estimate the study's short-run error correction model. 


\section{The Empirical Result}

\section{Dynamic Short-run Error Correction Model Result}

Table 4: Dependent Variable: Gross Domestic Product Growth (GDP)

\begin{tabular}{ccccc}
\hline Variable & Coefficient & Std. Error & t-Statistic & Prob. \\
\hline C & $5.76 \mathrm{E}-17$ & $2.11 \mathrm{E}-16$ & 0.272762 & 0.7873 \\
D(LOGEEI) & $6.80 \mathrm{E}-16$ & $8.95 \mathrm{E}-16$ & -0.759638 & 0.0046 \\
D(LOGEEI(-1)) & $-2.34 \mathrm{E}-16$ & $1.00 \mathrm{E}-15$ & 0.232811 & 0.8178 \\
D(LOGHEI) & 1.000000 & $5.20 \mathrm{E}-15$ & $1.92 \mathrm{E}+14$ & 0.0000 \\
D(LOGHEI(-1)) & $-5.30 \mathrm{E}-15$ & $5.21 \mathrm{E}-15$ & -1.017113 & 0.3188 \\
D(MMR) & $2.76 \mathrm{E}-13$ & $5.54 \mathrm{E}-14$ & 4.984478 & 0.0000 \\
D(MMR(-1)) & $-2.77 \mathrm{E}-13$ & $5.55 \mathrm{E}-14$ & -4.992040 & 0.0000 \\
D(LER) & $2.00 \mathrm{E}-13$ & $4.00 \mathrm{E}-14$ & 4.986942 & 0.0000 \\
D(LER(-1)) & $-2.03 \mathrm{E}-13$ & $4.06 \mathrm{E}-14$ & -5.000015 & 0.0000 \\
D(INF) & $3.33 \mathrm{E}-18$ & $4.80 \mathrm{E}-18$ & 0.693346 & 0.4945 \\
D(INF(-1)) & $-1.09 \mathrm{E}-17$ & $4.69 \mathrm{E}-18$ & -2.315533 & 0.0291 \\
ECM(-1) & -0.541548 & 0.000774 & -1.999019 & 0.0566 \\
\hline \hline R-squared & 0.675432 & & & \\
F-stat. & $1.09 \mathrm{E}+28$ & & & \\
Prob(F-stat.) & 0.000000 & & & \\
Durbin-Watson stat & 2.104824 & & \\
\hline
\end{tabular}

Source: Author's Computation Using Data Extracted From WDI, 2019

According to the dynamic short-run error correction result in the table above, the current education spending index has a positive and considerable impact on economic growth as measured by GDP. This means that a $1 \%$ increase in present education spending will result in a $6.80 \%$ rise in economic development, implying that education investment can boost economic growth in Nigeria, potentially triggering $6.80 \%$ growth in the economy as a whole. In a similar vein, the prior education expenditure index for period 1 has a negative but 2.3 and minor impact on economic growth, suggesting that a $3 \%$ increase in education expenditure the previous year will result in a 2.3 per cent loss in economic development. In addition, the current health spending index has a favourable and considerable impact on economic growth. This means that a $1 \%$ increase in the health expenditure index will increase by a 1.0 per cent rise.

Furthermore, given the current climate, inflation has a positive and minor impact on economic growth, suggesting that a $1 \%$ increase in inflation will result in a 3.33 per cent decline in economic growth. This will happen because an increase in inflation will lead to a rise in unemployment. If the economy has a high unemployment rate, term taxes will be reduced, meaning the government will not earn as much revenue, decreasing GDP. Furthermore, life expectancy has a positive and significant impact on economic growth, with a $1 \%$ increase in life expectancy, leading 
to a $2.0 \%$ increase in economic growth. This result also suggests that the percentage of people expected to live can determine the rate of economic growth.

Furthermore, the current year's maternal mortality rate has a favourable and considerable impact on economic growth. This means that a $1 \%$ rise in maternal mortality would result in a 2.76 per cent increase in economic growth. Thus, the combination of education and health expenditures reveals that the government's present education and health spending will boost Nigeria's economic growth.

The results of the error correction model reveal that ECM is negative and significant, signifying the speed with which the short-run disequilibrium to long-run equilibrium is adjusted. The error correction model (ECM) was also shown to be statistically significant at the $5 \%$ level, with a co-efficient of -0.54158 , indicating that 54.1 per cent of the distortion in the short run is rectified in the first year of achieving equilibrium. The R-squared shows that all explanatory variables together account for around 67.5 per cent of the variation in economic growth in terms of the model's appropriateness. The Durbin-Watson value of 2.1 indicates that the model is well described because there is no serial correlation.

However, Ese (2014) discovered that recurrent expenditure had a negative impact on education in his study of public education expenditure and growth in Nigeria: A disaggregated approach. This study contradicts the current study. At the same time, Safe, Siew, and Mechmet, 2015, published a study titled effects of government education and health expenditures on economic growth: a meta-analysis, and the results show that education has a positive effect on economic growth, while health has a negative effect. However, in one sense, this is contradictory, while in another sense, it is correct. We also have empirical analyses on public expenditure for education and economic growth: evidence from Indonesia and effects of government education and health expenditures on economic growth: a metaanalysis by Suwandaru, Alghamdi, and Nurwanto, 2021, and Sefa, Churchill, Monash, and Mehmet, 2015. According to their findings, education and health have a positive impact on economic growth in the short run, but have a negative impact in the long run. However, our research shows that there is a positive impact in both the short and long run. While the other has a positive and negative impact on economic growth, this study has a positive and negative impact on economic growth in one aspect. As a result, based on the aforementioned studies, it was discovered that some of the studies are consistent with current studies while others are not.

\section{CONCLUSION AND POLICY RECOMMENDATIONS}

The empirical evidence from Nigeria is used to undertake an empirical analysis of health expenditure, education, and economic performance. The estimating methodology used in this study is a dynamic short-run error correcting model (DSECM). The study concludes that combining education and health spending shows that the government's current education and health spending will increase Nigeria's economic growth. Consequently, the maternal mortality rate for this year has a positive and significant impact on economic growth. This suggests that a $1 \%$ decrease in maternal mortality would increase economic growth by 2.76 per cent. This conclusion is intimately linked to Nigeria's education and health sectors, both of which have been demonstrated to require development. And, if caution is not used, the industry may worsen even further. 
The current education spending index has a favourable and significant impact on GDP growth. This suggests that a $1 \%$ increase in current education expenditures will result in a $6.80 \%$ increase in economic development, meaning that education investment in Nigeria can promote economic growth, potentially triggering a $6.80 \%$ growth in the economy whole. In a similar vein, the past education expenditure index for period 1 is negative by 2.3 per cent. It has a minimal impact on economic growth, implying that a $3 \%$ rise in education spending the previous year will result in a 2.3 per cent loss in economic growth. Another finding of the study is that other variables such as life expectancy, inflation, and maternity mortality rate all require immediate attention to complement education and health expenditure in Nigeria.

However, based on the findings, the following policy recommendations are made.

According to the study, it is logical for the government to increase its spending on existing health and education infrastructure in order to stimulate economic growth. Even so, this policy would then lead to a reduction in the horrible condition and standard of the education and health sectors, which may result in a reduction in capital flight owing to the fact those Nigerians seeking the best health and education infrastructure oversea, as there will be more accessibility and enhanced health and education services in Nigeria.

The government's education spending should also be risen in order to improve Nigeria's educational attainment. This is because, profit making by private schools' establishment in education cannot increase literacy rates as much as public investment can. This is recommended because the previous period's literacy rate had a significant impact on economic growth.

The federal government should also raise their annual allotment to the health sector to enhance Nigerians' overarching life expectancy. This policy recommendation contradicts the findings of our analysis, but it is requisite for Nigeria to progress from one level of economic growth to another and then advancement is achieved.

According to the study, it is absolutely essential to have a lasting increase in life expectancy resulting in an increase in public confidence; thereby, a rise in life expectancy would definitely not cause population to also increase as anticipated if significant investment is not made in health and education.

In the same vein, government allocation in various sectors of the economy should be strictly monitored, so as to prevent the act of corruption, that is siphon of funds from public to private government officers' account More so, government should increase productive public expenditure on education and health, but in a way of meeting trade labour requirements and accelerating the transition of degree holders to trade labor. The development of education and health policies must be based on analysis and research.

On this premises, similar research could be replicated to cover the period of study up to 2020 in order to include new reforms implemented in Nigeria in the education and health sectors that are not covered by the study. Furthermore, other research could be conducted to take into account other African countries other than Nigeria, resulting in research with a broader scope and grounds for juxtaposition.

\section{CONFLICT-OF-INTEREST DISCLOSURE}

I will like to declare on behalf of all authors that, there is no conflict of interest in sending this scholarly paper to the open journal Nigeria for publication. 


\section{ACKNOWLEDGEMENTS}

Firstly, no funding is available for this research. The authors did not receive support from any organization for the submitted work. Secondly, I want to appreciate all the people that have contributed in one way or the other to the success of this scholarly paper. Also, more appreciation goes to those works that were cited in the paper. Thank you so much and God bless you all

\section{REFERENCES}

Bedir, S. (2016). Healthcare Expenditure and Economic Growth in Developing Countries. Advances in Economics and Business 4(2): 76-86, 2016 http://www.hrpub.org DOI: 10.13189/aeb.2016.040202

Salgar, S., Eckert, M; Izenberg, S. \& Martin, M. J. (2013). The effects of tranexamic acid and prothrombin complex concentrate on the coagulopathy of trauma. An in vitro analysis of the impact of severe acidosis. Journal of Trauma and Acute Care Surgery.75(6); 954 - 960 doi: 10.1097/TA.0b013e31829e20bf

Taofeek, O. A, Abiodun, S. B \& Oluwatosin A., (2020). Modelling Central Bank behaviour in Nigeria: A MarkovSwitching Approach. Journal of Homepage. 20(4); 213 - 221.

Lucas Jr. R E., (1988). On the Mechanics of Economic Development. Journal of Monetary Economics, 22(1); 3 - 42.

Romer, P. M., (1990). Endogenous Technological Change. Journal of Political Economy. 98(5), Part 2

Dawson, P. J \& Lingard, J., (1982). Management bias and return to scale in a Cobb-Douglas Production Function. European Review Agricultural Economics; 9(1): 7 - 24

Barro and Salai, (1995)

Wong Sing Yun (2021). Impact of Demographical Structural Change on Public Health Care Expenditure in Malaysia. Apply Economics Journal. 28(2)

Victor, S. E, Emmanuel C. O., \& Ugwuanyi, C. S. (2021), Assessment of The Extent of Community Involvement In The Funding Of Primary Schools In Enugu State, Nigeria: Implications For Further Research. International Journal of Mechanical and Production Engineering Research and Development. 10(1); 91-98

Eggoh, Houeninvo, and Sossou (2015). Determinants of Africa's Development: An Exploratory Study. The Journal of Development, 56(1); 267 - 317: 10.1353/jda.2022.0002

Kheira, B., \& Taouche, K., (2020). The impact of public spending on economic growth in Algeria. Economic and Management Research Journal. 14(1); 185-203.

Simeon, G., N., \& Igbogidi, E. D., (2021). Primary School Enrolment, Public Spending on Education and Economic Growth in Nigeria. Mediterranean Journal of Social Sciences, 12(5)

Mohammed, B.; Gabel, M.; Karlsson, L. M., (2013). Comparative Effect of Eucalyptus Camadulensis and Aloe Barbadensis on Salmonella Typhi. Nigerian Journal of Scientific

Mallick, L., Das, P. K., \& Pradhan, K. C., (2016). Impact of educational expenditure on economic growth in major Asian countries: Evidence from econometric analysis. Theoretical and Applied Economics. 13(2); 173 - 186.

Eggoh J., Hilaire G. H \& Gillies A.S (2015); Education, health and Economic Growth in African Countries; Journal of Economic Development, 93.

Hafiz M.A, Ghulam M. \& Adiga K. (2018); Health, Education and Economic Growth Nexus: Evidence from MddleIncome Countries; Global Social Sciences and Review; (3), 68 
Ozturk, I. (2001); The Role of Education In Economic Development: A Theoretical Perspective; Journal of Rural Development and Administrative; (13), 34-47

Salgur S.A. (2013); The Importance of Education on Economic Growth; Euromentor Journal; (4), 51-53

Jude E., Hilaire H. \& Gilles-Armand S., (2015); Education, Health and Economic Growth in African Countries; Journal of Economic Development; 40(1), 94

Verberne, P., van Zon, A.H, and Muysken, J. (1996), A three-sector endogenous growth model with combined technological change: the choice between basic innovations and quality improvements', MERIT (Maastricht Economic Research Institute on Innovation and Technologie) Research Memoranda, 2/96-015, MERIT, Maastricht.

Wong S. Y., \& Remali Y., (2018); Revisiting Long-Run Dynamics Of The Determinants Of Public Education Expenditure In Malaysia; Journal of the Asian Academy of Applied Business; 5, 29 - 44.

Lee W., \& Jei (2019); Study of the Relationship between Government Expenditures and Economic Growth for China and Korea; MDPI Publishing Journal; 11, 6344.

Akpan, U. F., \& Atan, A. J. (2015). Macroeconomic effect of fiscal policy shocks in Nigeria: A SVAR approach. International Journal of Business and Economic Research, 4(3), 109- 120.

Ayeni, A. O., \& Omobude, O. F. (2018). Educational Expenditure and Economic Growth Nexus in Nigeria. Journal for the Advancement of Developing Economies, 7(1), 2161-8216.

Birhanu Y. A \& Robert O., (2020), Healthcare Expenditure and Economic Growth in Sub-Saharan Africa, Asian Journal of Economics Business and Accounting, 13(2).

Adetula, D. T., Adesina, K., Owolabi, F., \& Ojeka, S. (2017). Investment in Education for the Nigerian Economic Development. Journal of Internet Banking and Commerce.

Mohammed I. \& Imoughele L., (2015), Macroeconomic Determinants of Economic Growth in Nigeria: A Cointegration Approach, International Journal of Academic Research in Economics and Management Sciences, 4

Hanushek E A \& Wobbmann L (2010), Education and Economic Growth. In: Penelope Peterson, Eva Baker, Barry McGaw, (Editors), International Encyclopedia of Education, 2, 245-252.

Robert J. B \& Xavier S. I (1995), Technological Diffusion, Convergence and Growth, Journal of Economic Growth, 2(1): $1-26$.

Robert E. L., (1987), Journal of Monetary Economics, on the Mechanics of Economic Development, 3-42

Wong S. Y \& Remali Y., (2018), Revisiting Long-Run Dynamics of the Determinants of Public Education Expenditure in Malaysia, 5: 29-44.

Wahab, A., O., A. A., Kefeli, Z. \& Nurhazirah, H. (2018). Investigating the dynamic effect of healthcare expenditure and education expenditure on economic growth in organisation of Islamic countries (OIC). MPRAPaper, No. 90338.

Oseni I. O. Sakiru O. A., Daniel A. B. \& Soliu B. A., (2020), Government spending and school enrolment in subSaharan Africa: A system GMM approach, Journal of Economics and Management, 40 (2): 92-108. 